\title{
Groundwater resources and hydro-environmental problems in China
}

\begin{abstract}
Groundwater supplies have played a key role in economic progress in China. However, the irrational development of water resources may lead to a variety of environmental problems including the expansion of desertification in arid areas, groundwater pollution, saline intrusion and land subsidence. Ways are heing investigated to alleviate the consequences of past practice and to develop methods for the prediction of potential problems.
\end{abstract}

\section{Introduction}

An enormous amount of investigation and research work, including regional hydrogeological surveys and specific prospecting work, has been undertaken during the past 40 years to facilitate water supply to many cities, industrial bases. and agricultural areas. Consequently, groundwater has become an important water source and has played an important role in developing industry, agriculture, and municipal construction, particularly in north China. Unfortunately, many environmental problems have occurred here and there as a direct result of groundwater development. Effective measures are needed to prevent such man-made disasters.

\section{The regional characteristics of groundwater}

China has a total land area around 9.6 million $\mathrm{km}^{2}$. To date, more than two thirds of the territory has been covered by regional hydrogeological surveying. During the investigation, an assessment of the regional groundwater resource, chiefly calculated by the method of water balance, has also been made. According to preliminary results, the total amount of annual precipitation is about $6 \times 10^{12} \mathrm{~m}^{3}$ for the whole country, while the total natural groundwater resource is around $8716 \times 10^{8} \mathrm{~m}^{3}$ /year (Chen, 1987).

As for regional distribution, $70 \%$ of pore water occurs in north China, and only $30 \%$ in south China; while fissure water in the south is three times that of the north, and more than $90 \%$ of karst water is in the south (Table 1). It is clear that pore water in the north and karst water in the south are playing important roles as resources.

Table 1 Distribution of groundwater resources in north and south China $\left(10^{8} \mathrm{~m}^{3} /\right.$ year $)$.

\begin{tabular}{|c|c|c|c|c|c|c|c|c|}
\hline Arca & $\begin{array}{l}\text { Pore } \\
\text { water }\end{array}$ & $\%$ & $\begin{array}{l}\text { Fissure } \\
\text { water }\end{array}$ & $\%$ & $\begin{array}{l}\text { Karst } \\
\text { water }\end{array}$ & $\%$ & Total & $\%$ \\
\hline $\begin{array}{l}\text { North } \\
\text { China }\end{array}$ & 1773.17 & 70 & 1139.55 & 27 & 192.64 & 9 & 3105.36 & 35.6 \\
\hline $\begin{array}{l}\text { South } \\
\text { China }\end{array}$ & 730.37 & 30 & 3034.08 & 73 & 1847.03 & 91 & 561148 & 64.4 \\
\hline$\overline{\text { Total }}$ & \multicolumn{2}{|l|}{2503.54} & \multicolumn{2}{|l|}{4173.63} & \multicolumn{2}{|l|}{2039.67} & \multicolumn{2}{|l|}{8716.84} \\
\hline
\end{tabular}

Table 2 Amounts of groundwater extracted in north and south China $\left(10^{8} \mathrm{~m}^{3}\right.$ /year $)$.

\begin{tabular}{c|l|l|l|l} 
Area & Pore water & Fissure water & Karst water & Total \\
\hline North & 540.35 & 5.51 & 94.63 & 640.49 \\
China & $(72.41 \%)$ & $(0.74 \%)$ & $(12.68 \%)$ & $(85.83 \%)$ \\
\hline South & 26.36 & 12.27 & 67.15 & 105.78 \\
China & $(3.53 \%)$ & $(1.64 \%)$ & $(9.00 \%)$ & $(14.17 \%)$ \\
\hline Total & 566.71 & 17.78 & 161.78 & 746.27 \\
& $(75.94 \%)$ & $(2.38 \%)$ & $(21.68 \%)$ & $(100 \%)$
\end{tabular}

According to statistics, the total annual amount of of groundwater exploited throughout the country is about $746 \times 10^{8} \mathrm{~m}^{3}$, which is $11.6 \%$ of the groundwater resource; $76 \%$ of the groundwater exploited annually is from plain areas and $24 \%$ from hilly land. With regard to distribution, $86 \%$ of the annual extraction is in the north and $14 \%$ in the south (Table 2). In the plain areas of north China, the extraction of groundwater is about $72 \%$ of the total. compared to only $3.5 \%$ in south China. The exploitation of groundwater in the plain areas of north China is chiefly for agricultural use and forms the major part of consumption.

\section{Problems in semi-arid and arid regions}

\section{Comprehensive treatment in semi-arid areas}

The Huang-Huai-Hai plain of north China is in a typical semiarid area. It has an average annual precipitation from 400 to $800 \mathrm{~mm}$, and potential evaporation reaches 1100 to $1700 \mathrm{~mm}$. It is one of the most important cereal production areas of our country but in the central part of this wide plain, there is a combination of natural hazards such as drought, waterlogging and salinisation. They are inherently linked to each other and closely related to hydrogeological conditions. The water table is shallow and mostly about $1-2 \mathrm{~m}$ but shows periodical variations, chiefly controlled by precipitation and evaporation as well as exploitation. According to data from an experimental station in Shangqiu district, both the infiltration of precipitation-groundwater depth relation curve and the evaporation-groundwater depth relation curve reach the maximum and minimum values respectively at 3-4 $\mathrm{m}$ (Figures $1-3$ ). This makes it possible to determine an optimum groundwater level to maximise infiltration of rainfall and to minimise evaporation by well-pumping (Chen and Xu, 1986).

A successful experiment known as the 'Shangqiu experience' was carried out in Shangqiu district for the comprehensive control of drought, waterlogging and salinisation. The water table was maintained by pumping at a depth of 3-5 m, which not only increases the infiltration of precipitation to recharge but also reduces evaporation of shallow water to a minimum. In this way, more than $40 \times 10^{8} \mathrm{~m}^{3}$ per year of groundwater, previously lost to evaporation, becomes usable. In addition, the aeration zone has a larger storage capacity which can be used as a subsurface regulated reservoir in the long term. According to calculations, the exploitable water resource has increased from $7.45 \times 10^{8} \mathrm{~m}^{3}$ to $12.89 \times 10^{8} \mathrm{~m}^{3}$. 

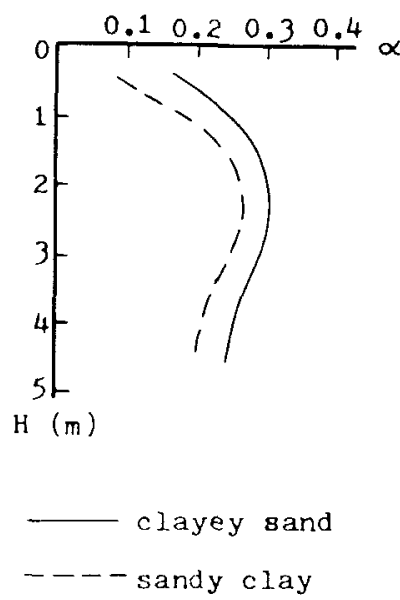

Figure $1 \alpha-H$ relation curves (precipitation 70 mm over one hour interval).

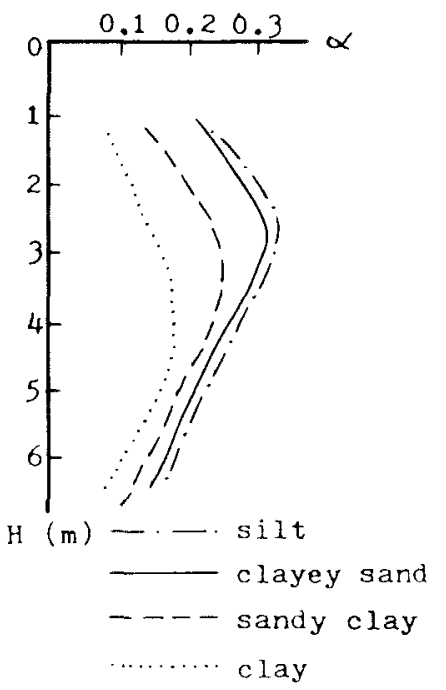

Figure $2 \alpha-H$ relation curves of the Yellow River alluvial plain, Shandong Province.

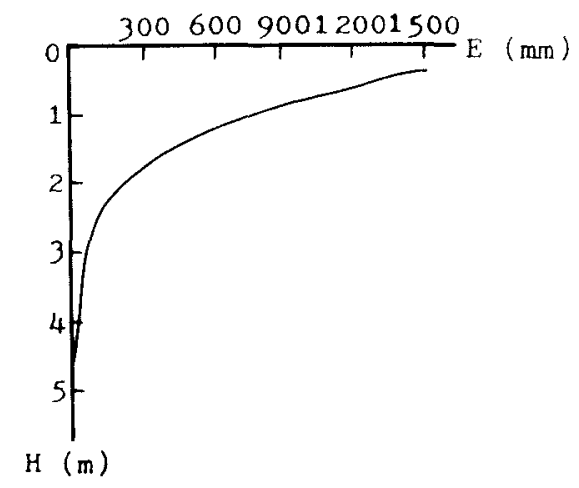

Figure $3 E-H$ relation curve at a balance experiment site at Dawuzhuang, Shangqiu, 1984. The aeration zone is composed of clayey sand.

By way of long-term comprehensive harnessing and controlling, more than 400000 wells have been drilled in the area with an annual pumping rate of $50 \times 10^{8} \mathrm{~m}^{3}$ from a shallow aquifer. Over $80 \%$ of the area, the water table was kept at regular depths of $2-4 \mathrm{~m}$ and 4-6 m depending on the season. As a result, the area under irrigation was rapidly expanded; the area of saline land was reduced from 210000 to $66700 \mathrm{ha}$, while waterlogging is well controlled. The ecological environment has been greatly improved, and agricultural production has increased.

\section{Ecological effects in arid areas}

Enormous inland basins in north-west China fall in the Gobi desert area. The annual precipitation is extremely low, but streams which originate from the melting snow and rainfall in high mountains such as the Tianshan and Qilian mountains, carry large volumes of surface runoff onto the piedmont plain. Almost $60 \%$ to $80 \%$ of the runoff penetrates the ground via gravel beds in the Gobi area to emerge in spring clusters on the frontal part of the alluvial fan. It then flows into the so called Oasis to become the chief water source for irrigation. The Hexi Corridor is a typical example. Infiltration of streams and canal seepage loss, accounts for nearly $90 \%$ of the total groundwater recharge while infiltration of local rainfall is only around $6 \%$. The outflow of spring clusters reaches $45 \%$ of the total discharge (Chen, 1990).

During the past 30 years, many reservoirs and cemented channels have been built for the development of water resources. These have resulted in the reduction of groundwater recharge, a drastic decline in groundwater levels and a depletion of spring outflows. On the other hand, the high consumption of water resources in the upper reaches have caused rapid decreases of the inflow into the lower basin, even the interruption of the streams. These tremendous changes in the water environment by human activity have seriously affected the ccologic system of the whole region. The extensive fall in groundwater levels in the lower reaches has caused the decay of vegetation, degeneration of the pasture, deterioration of water quality and the disappearance or reduction of terminal lakes. The final result is the expansion of desertification. For example, the so-called 'green corridor' with a length of more than $300 \mathrm{~km}$ on the lower reaches of the Tarim river, the biggest river in Xinjiang, has almost disappeared and is threatened by desertification. The most pressing hydro-environmental problem in arid areas is how to prevent the harmful ecologic effects of such irrational water development.

\section{Problems in urban areas}

According to incomplete statistics, among the 181 large and medium cities throughout the country, 61 rely chiefly on groundwater for water supply, and 40 use groundwater and surface water conjunctively. The different grades of exploitation of groundwater in 27 major cities in north China, enables the cities to be classified into four types depending on the characteristics of the groundwater exploitation regimes. Among these 27 cities, 16 belong to depletion and over-exploitation types and the rest belong to balanced and stable types.

The main problems in groundwater resources development in urban areas are water pollution and negative environmental effects of groundwater over-exploitation, such as land subsidence and seawater intrusion. Based on the data of groundwater quality monitoring for many years, and using methods such as regression analysis, trend extrapolation, probability statistics, and hydrodynamic dispersion, the trends of the polluted substances such as total hardness, mineralisation, nitrates. COD, chlorides in groundwater in urban areas for the above-mentioned 27 cities up to the year 2000 have been predicted. For each polluted substance a grade $T_{i}$ is given according to the $\mathrm{C}_{\mathrm{i}} / \mathrm{C}_{\mathrm{oi}}$ value. Using the formula:

$$
\mathrm{T}=\sum_{\mathrm{i}=1}^{n} \mathrm{~T}_{\mathrm{i}}
$$

a comprehensive index of trends $\mathrm{T}$ is obtained for each city. The trends are evaluated and classified into five classes as shown in Table 3 (Li, 1988). This shows that the groundwater quality will be very rapidly or rapidly deteriorated in 12 cities $(44.4 \%)$, rather rapidly and slowly deteriorated in 11 cities $(40.8 \%)$, and remains stable in four cities $(14.8 \%)$.

To mitigate land subsidence in Shanghai, a series of countermeasures have been taken since 1966, Consequently, the annual rate of subsidence has gradually decreased from $110 \mathrm{~mm} /$ year in 1961 to $2.5 \mathrm{~mm} /$ year in 1992, which means that land subsidence in the urban area of Shanghai has been almost brought under control.

A project for the prevention of land subsidence was carried out in Tianjin in 1985, and has already obtained effective results. The

Table 3 Comprehensive evaluation of the trends of groundwater pollution in urban areas up to 2000.

\begin{tabular}{llll} 
Classes of trends & Trend & Number of cities & $\%$ \\
\hline Very rapid deterioration & 20 & 4 & 14.8 \\
Rapid deterioration & $10-19$ & 8 & 29.6 \\
Rather rapid deterioration & $5-9$ & 4 & 14.8 \\
Slow deterioration & $1-4$ & 7 & 26.0 \\
Stable & 0 & 4 & 14.8
\end{tabular}


Table 4 Changes in the annual rate of subsidence in Tianjin.

\begin{tabular}{l|lllllll} 
& 1985 & 1986 & 1987 & 1988 & 1989 & 1990 & 1991 \\
\hline $\begin{array}{l}\text { Amount of } \\
\text { abstraction } \\
\left(10^{4} \mathrm{~m}^{3} / \text { year }\right)\end{array}$ & 9696 & 9662 & 8015 & 6645 & 5274 & 5182 & 4918 \\
\hline $\begin{array}{l}\text { Artificial } \\
\text { recharge } \\
\left(10^{4} \mathrm{~m}^{3} \text { /year }\right)\end{array}$ & 87 & 72 & 77.6 & 81.6 & 134 & 157.5 & 163.8 \\
\hline $\begin{array}{l}\text { Rate of } \\
\text { subsidence } \\
(\mathrm{mm} / \text { year })\end{array}$ & 86 & 62 & 43 & 24 & 18 & 15 & 17
\end{tabular}

measures chiefly included the closure of 630 production wells, with $4778 \times 10^{4} \mathrm{~m}^{3}$ of abstraction being curtailed. Meanwhile the amount of artificial recharge increased to $773.5 \times 10^{4} \mathrm{~m}^{3}$ (Table 4). As a result, the rate of annual subsidence decreased from $86 \mathrm{~mm}$ in 1985 to $17 \mathrm{~mm}$ in 1991 (Chen, 1994).

The process and prediction of seawater intrusion have been studied in some coastal urban areas of China. In Dalian, a correlation analysis has shown that the relationship between the concentration of chloride ions, $(\mathrm{Cl})$, the drawdown (s) and the yield $(\mathrm{Q})$ is as follows: $\mathrm{Cl}=21.6 \mathrm{~s}-1.4 ; \mathrm{Q}=4.07 \mathrm{~s}-2.14$. Taking $250 \mathrm{mg} / \mathrm{l}$ as the permissible concentration of chloride ions, one can determine that the permissible drawdown is $12.56 \mathrm{~m}$ and the permissible yield is $48.98 \times$ $10^{4} \mathrm{~m}^{3} /$ month. In Laizhou-Longkou, a prediction of seawater intrusion has been made by establishing a three-dimensional model of seawater intrusion, considering density-related flow. To mitigate seawater intrusion, a subsurface physical barrier was constructed at the mouth of the Huangshui river in Longkou, which formed a subsurface reservoir. In Beihai, Guangxi Autonomous Region, the border of the artesian aquifers at the bottom of the sea was determined graphically to calculate the permissible yield.

\section{Conclusion}

To solve these problems, extensive research work on mathematical and management models has been undertaken. However, most of the models have not been fully utilised in practice due to insufficient understanding of hydrogeology and a non-holistic approach. Not only designers and engineers, but also administrative officials should have a correct and comprehensive understanding of the rational development and utilisation of groundwater resources. Only then can a correct strategy and policy be adopted.

\section{References}

Chen Mengxiong, and Xu Zhirong, 1986, Groundwater systems of the Yellow River alluvial plain, north China: IAHS Publication no. 163.

Chen Menxiong, 1987, Groundwater resources and development in China: Environ Geol. Water Sci. vol. 10, no. 3, pp. 141-147.

Chen Mengxiong, 1990. Analysis of the hydrological system of Hexi Corridor, Gansu Province: IAHS Publication no. 197.

Chen Mengxiong, 1994. The control of land subsidence related to sea-level rise: Influence of sea level rise on delta areas of China and countermeasures: Science Press, Beijing, pp. 267-277.

Li Jingsen, 1988, The problems of groundwater quality and strategy in major cities of China: Research on environmental geology: Science Press, Beijing, pp. 6-15.

Zuhuang Cai, is a research fellow at the Institute of Geology, Chinese Acadamy of Sciences. He was born in Shanghai in 1934, and graduated in hydrogeology and engineering geology at the Leningrad Mining Institute in 1958. His research fields include the dynamics of groundwater, isotopic hydrogeology, engineering hydrogeology, environmental hydrogeology and seismological hydrogeology.

Mengxiong Chen is an Academician of the Chinese Academy of Sciences, a member of the Advisory Committee on Science and Technology of the Ministry of Geology and Mineral Resources (MGMR), a visiting Professor of the Changchun College of Geology and China University of Geosciences, a member of $I A H$, and a former chief hydrogeologist in the Bureau of Hydrogeology and Engineering Geology of MGMR. He has been mainly engaged in nationwide regional hydrogeology and has published widely both in China and abroad.
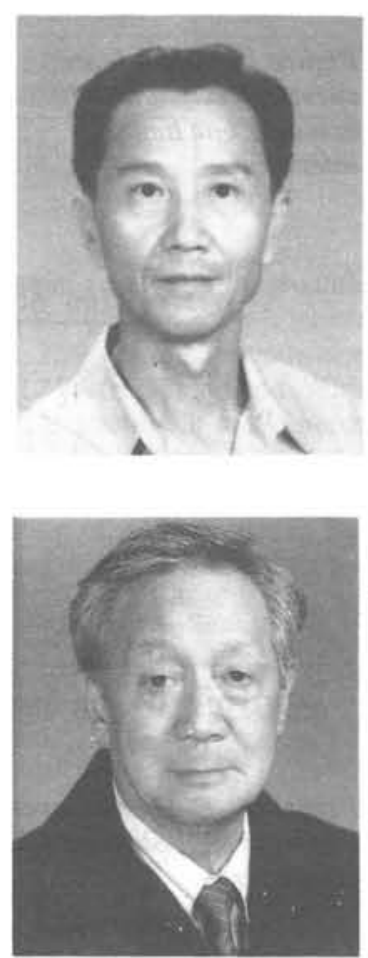